\title{
BIAS GENDER DALAM BUKU TEKS PELAJARAN BAHASA ARAB KARYA FARUQ BAHARUDIN: Studi Analisis Pada Buku Ajar Tingkat Madrasah Tsanawiyah Kelas VII
}

\author{
Adin Nur Kholiza ${ }^{1}$, Ningsih Fadhilah ${ }^{2}$ \\ 1,2 IAIN Pekalongan \\ Email: adinnurkholiza7@gmail.com¹, ningsih.fadhilah@iainpekalongan.ac.id²
}

\begin{abstract}
Abstrak:
Ketidakadilan gender yang terjadi pada pendidikan formal di sekolah tanpa disadari oleh guru atau siswa itu sendiri. Pada umumnya, guru merasa telah memperlakukan siswasiswinya secara adil. Mereka tidak memperhatikan dengan baik buku ajar yang berpotensi mengarah pada bias gender. Memperhatikan isi buku ajar adalah langkah penting yang berperan dalam merubah pola pikir para murid termasuk prilaku yang dianggap bias gender maupun responsif gender. Oleh karenanya tujuan penelitian ini adalah untuk mengetahui bias gender pada materi dan gambar ilustrasi buku teks pelajaran bahasa Arab karya Faruq Baharudin. Metode yang digunakan penelitian studi pustaka dengan pendekatan kualitatif. Adapun teknik analisis data menggunakan analisis semiotik. Hasil penelitian menunjukkan bahwa materi dalam buku teks pelajaran bahasa Arab karya Faruq Baharudin masih mengandung bias gender yang dilihat dari empat aspek: 1) peran kerja, 2) nilai sifat, 3) status sosial, dan 4) bias gender dalam kegemaran. Bias gender ini terdapat dalam tiga tema yaitu bab satu tema ta'aruf (Perkenalan), bab tiga tema adawaatul madrosiyyah (Peralatan sekolah), dan bab enam tema min yaumiyyatil usroh (Kegiatan sehari-hari keluarga) dan ada satu gambar ilustrasi yang mengandung bias gender, yaitu terdapat pada tema enam tentang min yaumiyyati lusroh (kegiatan seharihari keluarga).
\end{abstract}

Kata Kunci: Bias Gender, Buku Teks, Bahasa Arab

\begin{abstract}
:
Gender inequality that occured in formal education in schools was often unnoticed by teachers and students. In general, teachers thought that they had treated all their students fairly. They paid less attention and understand whether the textbooks they used were free from gender bias or not. Submission of textbooks was something that played a significant role in changing the mindset of students, including behaviors that were considered gender biased and gender responsive. The purpose of this study was to determine gender bias in the material and illustrations of Arabic textbooks by Faruq Baharudin. The method used was literature research with a qualitative approach. The data analysis technique used semiotic analysis. The results of the study indicated that the material in Faruq Baharudin's Arabic textbook still contained a gender bias which could be seen from four aspects: 1) work roles, 2) character values, 3) social status, and 4) gender bias in hobbies. This gender bias was contained in three themes, namely chapter one on the theme of ta'aruf (Introduction), chapter three on the theme of adawaatul madrosiyyah (school equipment), and chapter six on the theme of min yaumiyyatil usroh (Daily activities of the family) and there was a single illustration that contained bias. Gender, which was contained in theme six about min yaumiyyati lusroh (daily activities of the family).
\end{abstract}

Keywords: Arabic Language, Gender Bias, Textbook 


\section{PENDAHULUAN}

Buku teks pelajaran digunakan sebagai salah satu acuan guru dalam melakukan pembelajaran (Hedge, T., 2001). Buku teks pelajaran yang digunakan di sekolah tidak terlepas dari bias gender (Dewi Ulfah, Idawati, dan Sultan, 2019: 189). Pernyataan tersebut sesuai dengan adanya bias gender yang penulis temukan dalam beberapa buku teks pembelajaran bahasa Arab, dimana materi yang disajikan lebih didominasi dengan nama tokoh laki-laki dibandingkan dengan tokoh perempuan. Gambar ilustrasi yang terdapat dalam buku teks pembelajaran bahasa Arab juga menunjukkan adanya subordinasi bagi salah satu jenis kelamin (Foroutan, Y., 2012). Selain itu, substansi isi materi dalam buku teks pembelajaran bahasa Arab mengungkapkan posisi laki-laki yang lebih banyak bertempat pada wilayah publik (umum) dan perempuan ada di wilayah domestic (wilayah rumah tangga). Teks bahan ajar sangat penting dipeprhatikan dari nilai-nilai bias gender karena teks dianggap sebagai representasi dari nilai dan praktik social (Izzuddin, Dalimunthe, R. P., \& Susilo, S., 2021)

Perubahan besar yang berkaitan dengan relasi gender sangat penting di era millennium seperti sekarang ini, yaitu suatu hubungan yang mengharuskan kesetaraan peran antara perempuan dan laki-laki dalam kehidupan bersosial, berbangsa dan bernegara (Remiswal, 2013). Namun pada kenyatannya masih banyak perilaku sosial masyarakat yang mengandung bias. Adanya bias gender yang terjadi pada masyarakat tampaknya bermula dari pemahaman mengenai kodrat perempuan yang feminim, lemah lembut, dan keibuan, sedangkan laki-laki dilekatkan dengan maskulin, mempunyai tubuh yang kuat, dan berjiwa pemimpin (Forcey, L. R., 2016).. Sosialisasi gender seringkali terjadi dalam kehidupan sosial masyarakat. Selain itu, gender juga menjadi salah satu nilai-nilai atau fenomenafenomena yang disosialisasikan melalui pendidikan (Djamila Lasaiba, 2016). Lingkungan pendidikan memang sudah seharusnya mensosialisasikan kesetaraan gender dengan menciptakan proses pembelajaran yang responsif gender. Hal tersebut bertujuan untuk menanamkan sikap peduli gender dan pemahaman yang benar kepada para siswa mengenai kesetaraan gender (Mim, S. A., 2019).. Namun, 
tidak berbeda dengan kehidupan sosial masyarakat, bias gender juga seringkali ditemukan di lingkungan pendidikan.

Potensi terjadinya bias gender dalam lingkungan pendidikan sangat mungkin (Mengel, F., Sauermann, J., \& Zölitz, U., 2019), salah satu contoh di sekolah, posisi ketua kelas maupun ketua organisasi sekolah lebih banyak didominasi oleh siswa laki-laki daripada siswa perempuan. Hal ini disebabkan karena laki-laki dianggap lebih mampu menjadi pemimpin dibandingkan perempuan. Padahal seharusnya siswa perempuan juga mendapatkan hak yang sama untuk menjadi ketua kelas ataupun ketua organisasi di sekolah. Selain itu, bias gender juga kerap terjadi dalam proses pembelajaran, salah satunya terdapat dalam buku teks pelajaran. Meskipun Departemen Pendidikan Nasional sudah berupaya menghindari adanya bias gender dalam buku ajar melalui perubahan kurikulum, akan tetapi pada kenyataannya masih ada beberapa bahan ajar yang mengandung bias (Cépeda, P., Kotek, H., Pabst, K., \& Syrett, K., 2021).

Beberapa penelitian tentang bias gender dalam buku teks pelajaran, diantaranya penelitian Billah Nurlaili Zulmi dan Refti Handini Listiyani (2017: 7), menyatakan bahwa buku Tematik Siswa Kurikulum 2013 yang ditelitinya mengandung bias gender. Bentuk-bentuk bias gender yang tersampaikan diantaranya melalui gambar ilustrasi dan teks cerita dikategorikan dalam beberapa aspek yakni bias gender dalam peran kerja, nilai sifat, status sosial, dan kegemaran. Penelitian yang dilakukan oleh Djamila Lasaiba (2016) pada buku ajar Bahasa Inggris juga menemukan adanya bias gender, terlihat pada isi buku lebih mengutamakan jenis kelamin tetentu dan merugikan jenis kelamin yang lain. Dalam buku ajar kelas IV masih ditemukan tiga tema yang mengandung bias dan lima tema pada buku ajar kelas V. (Djamila Lasaiba, 2016). Selain itu, penelitian Dewi Ulfah, Idawati, dan Sultan juga menemukan adanya bias...gender pada“buku teks Bahasa Indonesia"untuk"Sekolah Menengah Atas, yakni menyatakan bahwa wujud bias gender yang ditemukan pada posisi subjek-objek adalah stereotip dan subordinasi terhadap jenis kelamin perempuan (Dewi Ulfah, Idawati, dan Sultan, 2019).

Demikian juga Cépeda, P., Kotek, H., Pabst, K., \& Syrett, K. (2021), meneliti pada buku tentang linguistik, menemukan bahwa hampir semua penulis 
mendukung berjenis kelamin laki-laki sebagai subjek dan agen, dan secara teratur menstereotipkan kedua jenis kelamin. Argumen berjenis kelamin laki-laki hampir dua kali lebih sering daripada yang berjenis kelamin perempuan, dan lebih mungkin terjadi sebagai subjek dan agen. Selain itu, contoh kalimat sering melanggengkan stereotip gender. Penelitian lain dari Yonata, F., \& Mujiyanto, Y. (2017), tentang representasi gender dalam buku teks bahasa Inggris di Indonesia, dalam beberapa materi buku teks tersebut ditemukan dominasi laki-laki atas perempuan pada bagian latihan dan gambar, seperti dalam menggambarkan karakter laki-laki yang terlibat dengan pendidikan tinggi, sosial, dan kegiatan public. Bias gender masih kental terasa dalam buku teks atau bahan ajar Bahasa Arab (Suwardi, S., Anitah, S., Akhyar, M., \& Asrowi, A., 2017).

Peneliti memilih buku bahasa Arab karya Faruq Baharudin karena buku tersebut merupakan buku keluaran terbaru dari Kementrian Agama tahun 2020 yang pastinya sudah mengalami banyak perbaikan dari kurikulum sebelumnya. Kemudian belum ada penelitian lain yang meneliti buku ini dari segi bias gendernya. Berdasarkan uraian tersebut, maka tujuan penelitian ini adalah untuk mengetahui bias gender yang ada dalam materi dan gambar ilustrasi buku teks pelajaran bahasa Arab karya Faruq Baharudin.

\section{TINJAUAN PUSTAKA}

Bias adalah suatu kebijakan atau kondisi yang memihak pada salah satu jenis kelamin atau kesenjangan peran dan kesempatan antara laki-laki dan perempuan dalam kehidupan keluarga dan masyarakat (Shodiq, M. J., 2014). Kata "Gender" berasal dari bahasa Inggris yang mempunyai arti "jenis kelamin”. Dikutip dari buku Argumen Kesetaraan Gender karya Nassaruddin Umar, disebutkan bahwa gender dalam Webster's New World Dictionary diartikan sebagai perbedaan yang Nampak antara laki-laki dan perempuan dilihat dari segi nilai dan tingkah laku (Nassaruddin Umar, 2010). Bias gender terdiri dari dua kata yaitu bias dan gender. Bias dalam Kamus Besar Bahasa Indonesia mempunyai arti simpangan, sedangkan gender mempunyai arti sifat yang melekat pada perempuan maupun laki-laki. Bias gender dapat juga diartikan sebagai pembentukan sifat atau karakter laki-laki dan perempuan secara sosial dan kultural yang menguntungkan satu jenis kelamin dan 
merugikan jenis kelamin lainnya (Rakhmat Hidayat, 2011). Bias gender ini terjadi di semua bidang kehidupan, termasuk dalam lingkungan pendidikan. Perilaku bias gender muncul karena ketidakadilan gender atau Gender Inaquality (Agus Afandi, 2019). Seks merupakan istilah yang biasanya digunakan untuk membedakan lakilaki dan perempuan dari sisi anatomi biologi. Istilah seks lebih banyak berfokus pada tanda biologis seseorang yang meliputi perbedaan komposisi kimia dan hormon yang ada dalam tubuh, rangka fisik, reproduksi dan ciri biologis lainnya. Sedangkan gender lebih banyak berfokus pada aspek sosial masyarakat, budaya, psikologis dan hal-hal non-biologis lainnya (Janu Arbain Nur Azizah dan Ika Novita Sari, 2015).

Dalam lingkup pendidikan, bias gender sering dijumpai pada materi yang dimanifestasikan melalui buku teks pelajaran (Julianti, L., \& Ikhsanudin, I., 2019, Selvi, A. F., \& Kocaman, C., 2021). Bias gender dalam buku teks pelajaran terdapat dalam makna suatu teks maupun gambar yang dimuat di dalamnya (Ferree, M. M., \& Hall, E. J., 1990, Elmiana, D. S., 2019). Untuk mengetahui maknanya, perlu adanya analisis, salah satu analisis yang dapat diterapkan adalah analisis menggunakan teori tanda Charles Sanders Pierce. Menurut Pierce tanda "is something which stands to somebody for something in some respect or capacity", mengatakan bahwa tanda memiliki tiga aspek atau elemen yang saling berhubungan dalam hubungan triadik, yakni ground, object, dan interpetant (Alex Sobur, 2009). Ruang lingkup ketidaksetaraan gender sesuai dengan Teori semiotika Charles Sanders Pierce sebagaimana dikutip oleh Billah Nurlaili Zulmi (2017) dalam memahami makna suatu teks maupun gambar terbagi menjadi empat kategori, yaitu: Bias gender dalam peran kerja, Bias gender dalam nilai sifat, Bias gender dalam status social, dan Bias gender dalam kegemaran (Billah Nurlaili Zulmi dan Refti Handini Listiyani, 2017).

Indikasi terjadinya sosialisasi gender yang terdapat dalam pembelajaran dapat dibuktikan salah satunya melalui buku teks pelajaran. Untuk mengarah pada terwujudnya kesetaraan dan keadilan gender, maka ada beberapa hal yang perlu diperhatikan, seperti mengupayakan keadilan gender dikalangan staf dan pemimpin di sekolah, menghilangkan pembedaan pada peserta didik, dan meredam segala hal yang berpotensi menyebabkan terjadinya kekerasan dan diskriminasi 
gender melalui materi pengetahuan yang diajarkan, proses pembelajaran yang dilakukan, serta menentang segala ide dan pemikiran yang mengandung stereotip negative (Titis Thoriquttyas dan Nita Rohmawati, 2018). Bias gender masih ditemukan dalam buku bacaan wajib di sekolah yang sebagian besar mentransfer nilai atau norma yang berlaku dalam kehidupan sosial masyarakat. Misalnya dalam buku ajar terdapat pernyataan bahwa Ayah bekerja di kantor, di kebun, dan sejenisnya (sektor publik) dan Ibu disosialisasikan di dapur, memasak, membersihkan rumah, mencuci, dan sejenisnya (sektor domestik). Hal ini berarti sistem nilai gender yang disosialisasikan di sekolah akan berpengaruh pada kehidupan sosial di sekolah dan akan berlanjut sampai pada tataran kehidupan sosial di masyarakat. Hal ini mneunjukkan kesenjangan gender muncul dalam proses pembelajaran di sekolah, teutama dipengaruhi oleh buku-buku pelajaran yang belum berlandaskan pada peran gender yang seimbang. Untuk itu, perlu adanya perubahan guna mencapai keadilan dan kesetaraan gender karena akan berakibat pada ketimpangan salah satu gender, khususnya perempuan.

Bahasa Arab merupakan bahasa dengan struktur gramatika yang paling detail dan akurat menggambarkan sebuah kondisi, paling luas kosakatanya, dan paling mampu untuk memverbalkan ide dan perasaan manusia (Muhammad Zulifan, 2018). Bahasa Arab dikenal menjadi salah satu bahasa yang berpotensi mengandung bias gender. Jika dilihat secara struktural, jenis kelamin perempuan diberi ruang khusus dalam bahasa Arab (pada tataran kata) sehingga dapat ditemukan adanya kata benda, kata sifat, dan kata kerja untuk perempuan. Untuk itu, penggunaan bahasa Arab dalam komunikasi, baik secara lisan ataupun tulisan kerap ditemui adanya bias. Ketentuan dalam bahasa Arab yang mengandung bias gender diantaranya terdapat pada nama untuk perempuan (isim muannats), dimana isim muannats cukup disusun hanya dengan menambahkan satu huruf ( $\mathrm{Ta}^{\prime}$ marbuthoh) pada nama atau isim yang telah ada bagi laki-laki (Sulaimani, A., 2017). Tata bahasa ini mencerminkan cara pandang masyarakat Arab terhadap eksistensi perempuan sebagai bagian yang sangat kecil dari eksistensi laki-laki (Erlina, 2013). Selain itu, bias dalam bahasa Arab juga dapat dipengaruhi oleh faktor-faktor berikut: Kosakata bahasa Arab yang memiliki makna tidak tunggal, Penetapan rujukan kata ganti (Dhamir), Penetapan batas pengecualian (Istitsna), dan 
Penetapan arti huruf 'athaf (Zaitunah Subhan, 2015).

\section{METODE PENELITIAN}

Penelitian ini merupakan penelitian kualitatif, dirancang melalui penelitian literatur atau penelitian kepustakaan (library research) dengan objek penelitian buku teks bahasa Arab karya Faruq Baharudin tahun 2020. Teknik analisis data yang digunakan menggunakan teknik analisis semiotik (semiotycal analysis) dengan tahapan pertama, mengidentifikasi teks dan gambar ilustrasi“yang terdapat dalam buku teks pelajaran bahasa Arab karya”Faruq Baharudin. Kedua, menganalisis makna teks dan gambar ilustrasi menggunakan analisis semiotik dengan mengacu pada teori kesetaraan gender. Selanjutnya menyimpulkan hasil analisis bias gender dalam buku teks pelajaran bahasa Arab karya Faruq Baharudin. Buku ini diterbitkan oleh Direktorat KSKK Madrasah, Direktorat Jenderal Pendidikan Islam, Kementrian Agama RI tahun 2020 dengan jumlah halaman 144 halaman. Buku ini juga telah melalui penyuntingan dan penyelarasan bahasa oleh Pusat Penelitian dan Interkomunikasi Pengetahuan di Kerajaan Arab

Saudi. Materi dalam buku ini terdiri dari tujuh tema, yaitu: التَّعَارُف Ta'aruf (Perkenalan), الْمَفَقِق الْمَدْرَسِيَّة Marofiqul Madrosiyyah (Fasilitas Umum di Sekolah),

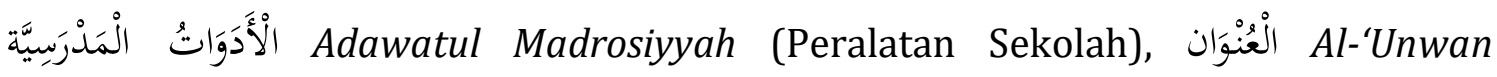
(Alamat), الْبَتْ Bayt (Rumah), dan مِنْ يَوْمياتِ الْعُسْرَ Min Yaumiyyatil Usroh (Kegiatan Sehari-hari Keluarga) (Faruq Baharudin, 2020).

\section{HASIL DAN DISKUSI}

Fokus penelitian ini adalah untuk mengkaji secara lebih mendalam adanya bias gender dalam materi dan gambar ilustrasi pada buku teks Bahasa Arab Karya Faruq Baharudin tahun 2020. Adapun ruang lingkup ketidaksetaraan gender/bias gender dalam penelitian ini sesuai dengan Teori semiotika Charles Sanders Pierce dalam Billah Nurlaili Zulmi (2017) bahwa dalam memahami makna bias gender 
pada suatu teks maupun gambar ilustrasi terbagi menjadi empat kategori, yaitu: Bias gender dalam peran kerja, nilai sifat, status social, dan Bias gender dalam kegemaran (Billah Nurlaili Zulmi dan Refti Handini Listiyani, 2017.

Oleh karenanya dari empat aspek bias gender di atas, penulis akan menganalisis dari dua hal yakni bisa gender pada materi teks Bahasa Arab dan kedua tentang bias gender pada gambar ilustrasi pada bukutersebut. Berdasarkan hasil analisis yang peneliti lakukan bahwa bias gender pada buku ini terdapat dalam tiga tema dari enam tema yang ada dalam buku, yaitu bab satu tema ta'aruf (Perkenalan), bab tiga tema adawatul madrosiyyah (Peralatan sekolah), dan bab enam tema min yaumiyyatil usroh (Kegiatan sehari-hari keluarga). Adapun data dan pembahasan dari penelitian ini secara lebih detail akan penulis paparkan sebagai berikut:

\section{A. Bias Gender dalam Materi Buku Teks Bahasa Arab Karya Faruq Baharudin}

\section{Bias gender dalam peran kerja pada materi teks Bahasa Arab}

Bias gender dalam peran kerja yang peneliti temukan dalam beberapa teks materi buku Bahasa Arab Karya Faruq Baharudin. Setiap teks yang mengandung bias gender dalam peran kerja mensosialisasikan tentang peran kerja domestik dan publik, diantaranya terdapat dalam tema ta'aruf (Perkenalan), meskipun tokoh yang berjenis kelamin perempuan dan laki-laki sudah sama-sama menempati sektor publik, namun tetap saja masih ada batasan- batasan dalam memilih pekerjaan. Kemudian tema enam tentang min yaumiyyatil usroh (Kegiatan seharihari keluarga) yang dengan jelas mensosialisasikan tokoh dengan jenis kelamin laki-laki berada pada sektor publik dan perempuan ada pada sektor domestik. Selain itu, materi dalam teks juga masih mengandung stereotype (Citra baku) dengan menyisipkan kalimat "Ibu menyiapkan makanan di dapur", "Adik perempuanku sedang membantu Ibu memasak di dapur", dan "Ayah sedang membaca koran" (Faruq Baharudin, 2020: 124-126).

Hasil penelitian tersebut dapat dikatakan mengandung bias gender. Hal ini sejalan dengan teori dari Muhammad Ja'far Shodiq yang menyatakan bahwa pembagian peran kerja yang dilakukan berdasarkan gender seringkali memunculkan diskriminasi, utamanya terhadap perempuan. Meskipun seiring 
dengan berkembangnya zaman sudah banyak perempuan yang melakukan pekerjaan di wilayah publik, akan tetapi masih ada batasan-batasan yang dibuat sendiri oleh masyarakat kepada perempuan dalam memilih pekerjaan. Ada beberapa pekerjaan yang dianggap cocok untuk perempuan karena perempuan dianggap sebagai makhluk yang tekun, sabar, dan rajin, maka pekerjaan yang cocok bagi perempuan adalah perawat, guru TK, kasir, atau sekretaris (Muhammad Jafar Shodiq, 2016). Hal tersebut juga sesuai dengan pernyataan Leny Nofianti dalam jurnalnya yang menyebutkan bahwa posisi perempuan dalam kebudayaan tidak sebaik posisi laki-laki. hampir semua kebudayaan di dunia menempatkan perempuan di belakang. Kemudian dikotomi pembagian peran kerja perempuan di wilayah domestik dan laki-laki di wilayah publik secara empiris semakin menenggelamkan perempuan kedalam urusan domestik (Leny Nofianti, 2016). Diperkuat lagi dengan adanya teori yang disebutkan oleh Ani bahwa perempuan lebih diperuntukkan menduduki peranan yang berkaitan dengan kehidupan rumah tangga. Bahkan budaya patriarki menyerahkan seluruh pekerjaan rumah tangga pada kaum perempuan tanpa melibatkan kaum laki-laki (Ani, 2017). Isu wanita karir masih menjadi bahan perdebatan yang tidak pernah ada habisnya. Banyak pihak yang membandingkan antara perempuan yang bekerja di luar rumah dan perempuan yang menjadi ibu rumah tangga. Memilih untuk bekerja diartikan dengan menelantarkan keluarga dan memilih menjadi ibu rumah tangga dianggap menyia-nyiakan gelar yang telah diraih (Ricka Handayani, 2020). Padahal, tidak ada yang salah dengan keduanya, masing-masing dapat dikerjakan dengan penuh tanggungjawab, baik urusan pekerjaan di luar maupun urusan dalam rumah tangga.

\section{Bias gender dalam nilai sifat pada materi Teks Bahasa Arab}

Perbedaan sifat antara laki-laki dan perempuan yang sering ditampilkan yaitu maskulin dan feminim. Beberapa materi dalam buku ini mensosialisasikan adanya sifat maskulin dan feminim. Seperti yang terdapat dalam bab satu tema ta'aruf (Perkenalan) dan bab enam tema min yaumiyyatil usroh (Kegiatan sehari-hari keluarga), dimana laki-laki dengan sifat maskulin dianggap lebih kuat dan 
perempuan dengan sifat feminim dianggap lebih lemah. Lebih jelas pada penjelasan teks bacaan pada gambar 1 di bawah ini:

Gambar 1: Teks Materi Bab 6 tentang Anggota Keluargaku

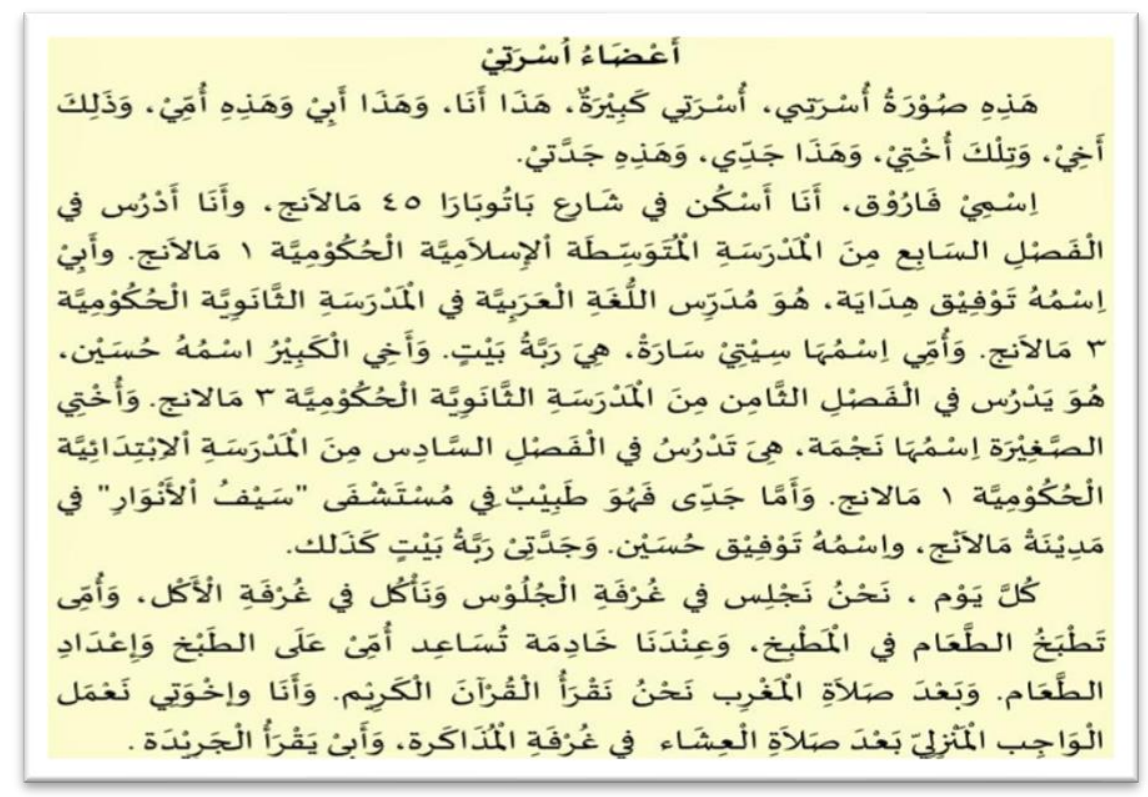

Terjemah teks: "Ini foto keluarga besarku. Ini saya, ini Ayah saya, ini Ibu saya, itu saudara laki-laki saya, itu saudara perempuan saya, ini Kakek saya, dan ini Nenek saya. Nama saya Faruq, saya tinggal di Jalan Batubara nomer 45 Malang. Saya belajar di kelas VII Madrasah Tsanawiyah Negeri 1 Malang. Ayah saya bernama Taufiq Hidayat, dia seorang guru bahasa Arab di Madrasah Tsanawiyah Negeri 3 Malang. Ibu saya bernama Siti Sarah, dia seorang ibu rumah tangga. Kakak laki-laki saya bernama Husein, dia belajar di kelas VIII Madrasah Tsanawiyah Negeri 3 Malang. Adik perempuan saya bernama Najmah, dia sekolah kelas VI di Sekolah Dasar Negeri 1 Malang. Adapun kakek saya bernama Taufiq Husain, Ia berprofesi sebagai Dokter di rumah sakit "Saiful Anwar" kota Malang, dan Nenek saya seorang ibu rumah tangga. Setiap hari, kami duduk di ruang keluarga, dan makan di ruang makan. Ibu saya memasak makanan di dapur, di sana juga ada pembantu perempuan yang membantu Ibu menyiapkan beberapa makanan. Setelah selesai salat Maghrib, kami membaca alquran, dan setelah selesai salat isya, saya dan saudara perempuan saya mengerjakan pekerjaan rumah di ruang belajar, dan Ayah membaca Koran (Faruq Baharudin, 2020, hal 124-126).

Dari teks tersebut dikonstruksikan dalam penggambaran pemilihan kerja. Laki-laki yang dianggap mempunyai fisik lebih kuat dari perempuan mempunyai pekerjaan yang memerlukan kekuatan dan kecakapan seperti pekerjaan dokter, sopir dan satpam. Kemudian perempuan yang dianggap lebih lemah mendapatkan pekerjaan yang membutuhkan ketekunan dan kesabaran seperti menjadi guru dan pembantu. 
Dokter dianggap sebagai pekerjaan yang lebih sesuai untuk laki-laki, karena pekerjaan ini dianggap membutuhkan logika. Laki-laki merupakan individu yang dipercaya lebih dapat menggunakan logika dari pada perempuan. Pelabelan bahwa perempuan adalah sosok yang feminim, lemah lembut, cenderung pendiam sedangkan laki-laki adalah sosok yang maskulin, kuat, tegas menyebabkan ketidaksetaraan gender dalam kehidupan sehari-hari (Shodiq, M. J. 2014).

Sesuai dengan hasil penelitian yang dilakukan oleh Luthfiyah Zahro, Aa Juhanda, dan Gina Nuranti bahwa kemampuan berpikir logis siswa pada konsep mata pelajarannya, siswa laki-laki yang mendominasi karena laki-laki lebih menggunakan logisnya dalam memahami pelajaran (Luthfiyah Zahro, 2020). Kutipan seperti itu jika diamati sangat bias gender. Salah satu stereotype gender mengatakan bahwa laki-laki lebih rasional (menggunakan logika), sedangkan perempuan lebih sering menggunakan perasaan. Pemikiran seperti ini berkembang di lingkungan masyarakat, yang kemudian dipatuhi dan diturunkan ke generasi selanjutnya.

Peletakan sifat maskulin dan feminim dalam teks materi ini dapat menimbulkan bias gender, sesuai dengan teori Ni Made Wiasti dalam jurnalnya yang menyebutkan bahwa Organ biologis yang dimiliki oleh laki-laki dan perempuan berbeda. Perempuan mempunyai organ tubuh yang diperlukan untuk kepentingan reproduksi seperti melahirkan. Sedangkan laki-laki tidak mengalami proses tersebut. Oleh karena itu, laki-laki dipandang lebih leluasa karena dapat menjalankan aktivitas dan lebih kuat dari perempuan (Ni Made Wiasti, 2017).

Hasil penelitian dari Nur Alifta Kinanti, Muhammad Irfan Syaebani, dan Dindha Vitri Primadini menyebutkan bahwa dari 129 pekerjaan di Indonesia, terdapat 46 pekerjaan yang merupakan pekerjaan maskulin, 57 pekerjaan netral, dan 26 pekerjaan feminim. Jika dibandingkan dengan penelitian sebelumnya, telah terjadi perubahan stereotip dimana dibandingkan dengan tahun 2020, penelitian terbaru ini menunjukkan semakin banyak pekerjaan yang bergerak kearah netral gender (Nur Alifta Kinanti, Muhammad Irfan Syaebani, dan Dindha Vitri Primadini, 2021). Hal ini menunjukkan bahwa masih terdapat stereotip pekerjaan berbasis gender di Indonesia, dimana laki-laki dominan dan perempuan dianggap sebagai second sex gender (Baghdadi, M., \& Rezaei, A., 2015). 


\section{Bias gender dalam status sosial pada materi teks Bahasa Arab}

Bias gender dalam status sosial adalah ketidaksetaraan gender yang terjadi akibat perbedaan kesempatan yang dimiliki perempuan dan laki-laki dalam hal kepemimpinan dan pendidikan. Dalam buku ini bias gender dalam status sosial pada materi buku ini ditemukan pada bab satu tema ta'aruf (Perkenalan) dan tema min yaumiyyatil usroh (Kegiatan sehari-hari keluarga). Pada tema ta'aruf (Perkenalan) yang memperkenalkan peran pemimpin yang diisi oleh laki-laki, dan peran untuk posisi pekerja kelas bawah seperti pembantu, dan karyawan diisi oleh perempuan. Lebih jelas pada penjelasan teks bacaan pada gambar 2 di bawah ini:

Gambar 2: Teks Materi Bab 1 tentang Nushus Tsani

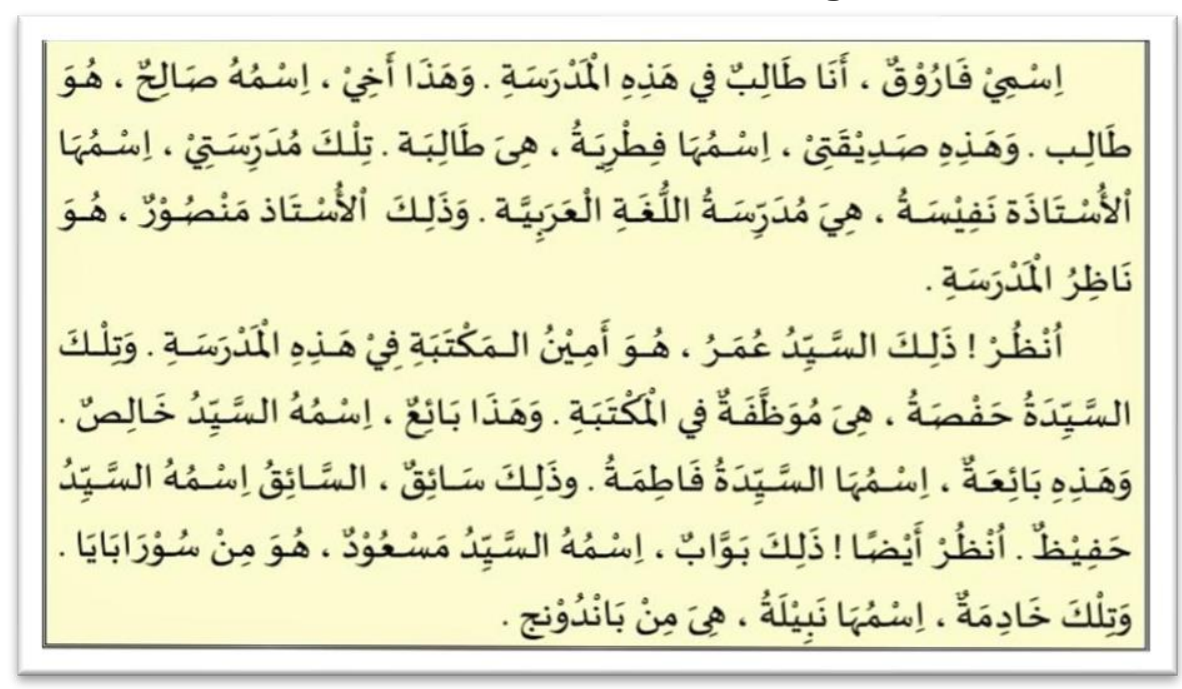

Terjemahan teks diatas: " Nama saya Faruq, saya siswa di sekolah ini. ini saudara laki-laki saya, namanya Sholih, dia seorang siswa, dan ini teman saya, namanya Fithriyah, dia seorang siswi. Itu guru saya, namanya ustadzah Nafisah, dia guru bahasa Arab, dan itu ustadz Manshur, dia kepala sekolah. Lihatlah! Itu pak Umar, dia kepala perpustakaan di sekolah ini, dan itu Ibu Hafshah, dia pegawai di perpustakaan. Ini seorang pedagang, namanya pak Kholis, dan ini juga pedagang, namanya Ibu Fatimah. Itu supir, supir itu bernama pak Hafidz. Lihat itu juga! Di sana ada satpam, namanya pak Mas'ud, dia berasal dari Surabaya, dan itu pembantu perempuan, namanya Nabilah, dia berasal dari Bandung(Faruq Baharudin, 2020, hal 10)."

Pada status kepemimpinan dalam pekerjaan dalam teks di atas, perempuan diposisikan tidak memiliki peran untuk memimpin suatu kegiatan. Pada tema satu tersebut, laki-laki ditempatkan menjadi seorang pemimpin. Kepemimpinan laki- 
laki ini termanifestasikan melalui perannya sebagai kepala sekolah dan kepala perpustakaan. Melalui peran sebagai kepala sekolah maupun kepala perpustakaan, laki-laki nampak menduduki posisi tertinggi di dalam struktur birokrasi sekolah. Kemudian dalam bab enam terdapat teks cerita yang memperkenalkan pekerjaan asisten rumah tangga yang diperankan oleh tokoh perempuan.

Kemudian dalam bab enam juga terdapat percakapan yang menyebutkan seorang okoh bernama Abdul Hakim yang sedang menempuh sekolah menengah pertama dan tokoh Salwa yang menempuh pendidikan sekolah dasar. Begitu juga dengan tokoh Ayah yang berprofesi sebagai dokter dan Ibu berprofesi sebagai guru. Pernyataan ini dengan jelas menyampaikan bahwa kedua tokoh tersebut setara dalam hal pendidikan. Hal ini sejalan dengan peraturan pemerintah nomor 47 tahun 2008 tentang wajib belajar yang mewajibkan pendidikan 12 tahun.

Pernyataan tersebut sesuai dengan Gender Role Theory yang menjelaskan bahwa gender menciptakan ekspektasi peran sosial akan bagaimana laki-laki dan perempuan sepatutnya berperilaku (Maulida Nurul Innayah dan Bima Cinintya Pratama, 2019). Sebagai contoh, pria dianggap lebih cocok sebagai pemimpin, berintelektual, mempunyai kemampuan analitis, mampu berfikir secara abstrak, dan mampu menyelesaikan masalah, dimana perempuan dianggap lebih hangat, baik, ekspresif, lebih ramah, dan sopan. Teori ini yang kemudian mempengaruhi persepsi orang di tempat kerja. Berdasarkan teori ini, pandangan mengenai gender secara otomatis cenderung menganggap pria lebih baik dalam melakukan kepemimpinan dibandingkan perempuan (Dawar, T. I. N. N. Y., \& Anand, S. A. R. I. T. A., 2017).

Hasil penelitian tersebut juga sesuai dengan teori yang disampaikan oleh Wami Tune Sumar dalam jurnalnya bahwa perempuan sebagai makhluk yang mempunyai sifat emosional, lemah lembut, dan penyayang dipandang tidak bisa menjadi pemimpin. Oleh karena itu, dalam dunia kerja seringkali posisi perempuan ditempatkan dibawah posisi laki-laki (Warni Tune Sumar, 2015). Laki-laki memiliki keunggulan dalam hal status atau kedudukan dalam beberapa aktivitas yang dilakukan di dalam substansi buku ini. Keunggulan yang nampak adalah penggambaran kepemimpinan dan perannya dalam hal pekerjaan. 


\section{Bias gender dalam kegemaran pada materi teks Bahasa Arab}

Nilai-nilai bias gender kegemaran diantaranya terdapat dalam bab satu tema ta'aruf (Perkenalan) dalam hal memilih pekerjaan, laki-laki lebih gemar terhadap pekerjaan yang mempunyai tantangan dan tingkatan karir yang lebih tinggi dan perempuan gemar melakukan pekerjaan domestik. Dalam bab tiga tema adawatul madrosiyyah (Peralatan Sekolah) dalam pemilihan warna, dalam buku ini laki-laki cenderung memilih warna yang netral gender seperti hijau, hitam, biru, dan merah. Sedangkan perempuan memilih warna yang lebih anggun seperti ungu, dan krem. Sebagaimana dipaparkan dalam gambar 3 tentang teks materi nasshul awwal berikut:

\section{Gambar 3: Teks Materi Bab 3 tentang Nasshul Awwal}

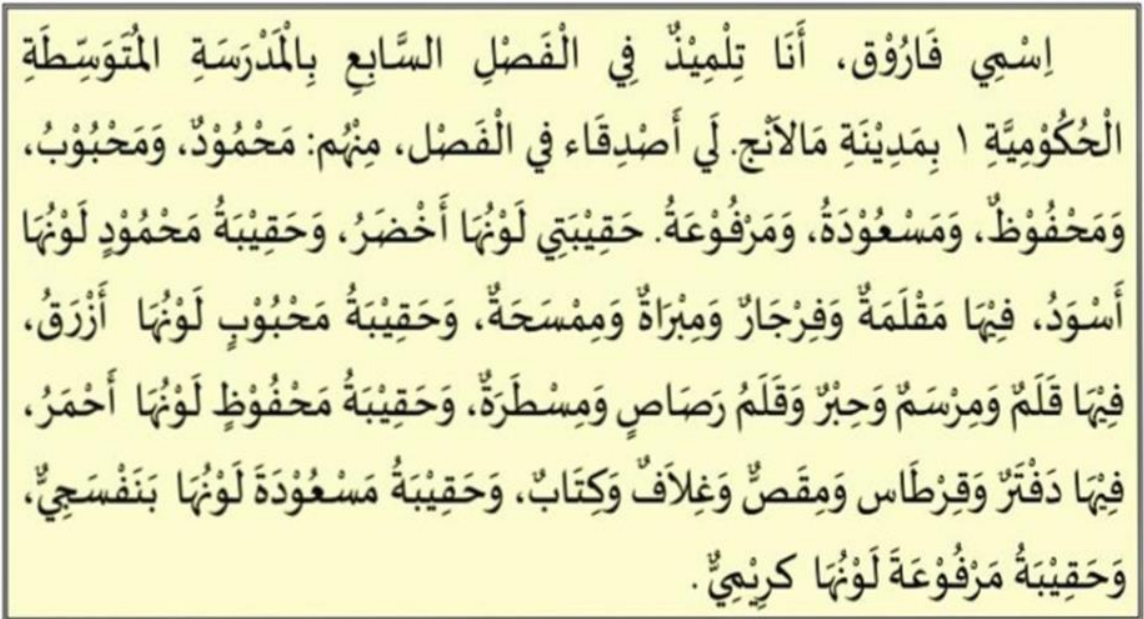

terjemahan teks: " Nama saya Faruq, saya siswa kelas VII di SMP Negeri 1 Kota Malang. Saya mempunyai banyak teman di kelas, diantaranya: Mahmud, Mahbub, Mahfudz, Mas'udah, dan Marfu'ah. Tas yang saya pakai berwarna hijau, tas Mahmud berwarna hitam. Di dalamnya terdapat tempat pena, jangka, rautan, dan penghapus. Mahbub menggunakan tas berwarna biru, di dalamnya terdapat pena, alat lukis, tinta, pensil, dan penggaris. Kemudian tas Mahfudz berwarna merah, di dalamnya terdapat buku tulis, kertas, gunting, sampul, dan buku. Mas'udah menggunakan tas berwarna ungu, dan Marfu'ah menggunakan tas berwarna krem (Faruq Baharudin, 2020: 57)."

Kemudian pada bab enam tema min yaumiyyatil usroh (Kegiatan sehari-hari) ada beberapa kalimat yang menyatakan Ibu memasak di dapur dan Ayah membaca Koran sebagaimana dijelaskan pada gambar 1 diatas. Ditampilkan beberapa kali dalam materi buku ini yang mengkonstruksikan bahwa perempuan gemar 
memasak dan laki-laki gemar membaca Koran. Adanya bias dalam kegemaran ini telah disosialisasikan sejak dini di lingkungan keluarga. Pemilihan permainan di masa kecil juga dapat mempengaruhi adanya bias dalam memilih pekerjaan. Anak dipilihkan mainan yang dianggap sesuai dengan jenis kelamin dan sifat yang diharapkan muncul dari anak tersebut. Misalnya, anak perempuan dibelikan mainan seperti boneka, peralatan memasak, dan lainnya. Sedangkan anak berjenis kelamin laki-laki akan dibelikan mainan yang dianggap lebih maskulin seperti bola, mobil-mobilan, senapan, dan lainnya.

Sebagaimana disebutkan oleh Amelberga Vita Astuti bahwa persepsi terhadap warna juga dipengaruhi oleh konteks sosial. Warna ungu dipersepsikan sebagai warna janda dan dianggap memberi pertanda buruk bagi perempuan yang memakainya. Karena bias gender ini, perempuan yang memakai pakaian berwarna ungu mengalami bentuk ketidakadilan gender dengan pelabelan warna ungu tersebut (Amelberga Vita Astuti, 2013). Kemudian ada beberapa warna yang dianggap cocok untuk jenis kelamin laki-laki dan warna yang cocok untuk jenis kelamin perempuan yaitu warna biru dikenal untuk laki-laki dan merah muda atau pink untuk perempuan. Hal tersebut juga sesuai dengan hasil penelitian Maulina Ismayanti yang menyatakan bahwa kecenderungan warna objek utama yang digambar oleh laki-laki yaitu warna biru dan kecenderungan warna objek utama yang yang digambar oleh perempuan adalah warna coklat (Maulina Ismayanti, 2015).

\section{B. Bias Gender dalam Gambar Ilustrasi Buku Teks Pelajaran Bahasa Arab Karya Faruq Baharudin}

Dari enam tema dalam buku Faruq Baharudin, ada 4 tema yang mengandung gambar ilustrasi. Adapun dari empat tema tersebut yang mengandung gambar ilustrasi dan teridentifikasi mengandung bias gender hanya ada satu tema yakni tema enam tentang min yaumiyyatil usroh kegiatan sehari-hari keluarga. Secara lebih detail dipaparkan dalam gambar 4 berikut: 


\section{Gambar 4: Ilustrasi dalam Tema 6 tentang Min Yaumiyyatil Usroh}

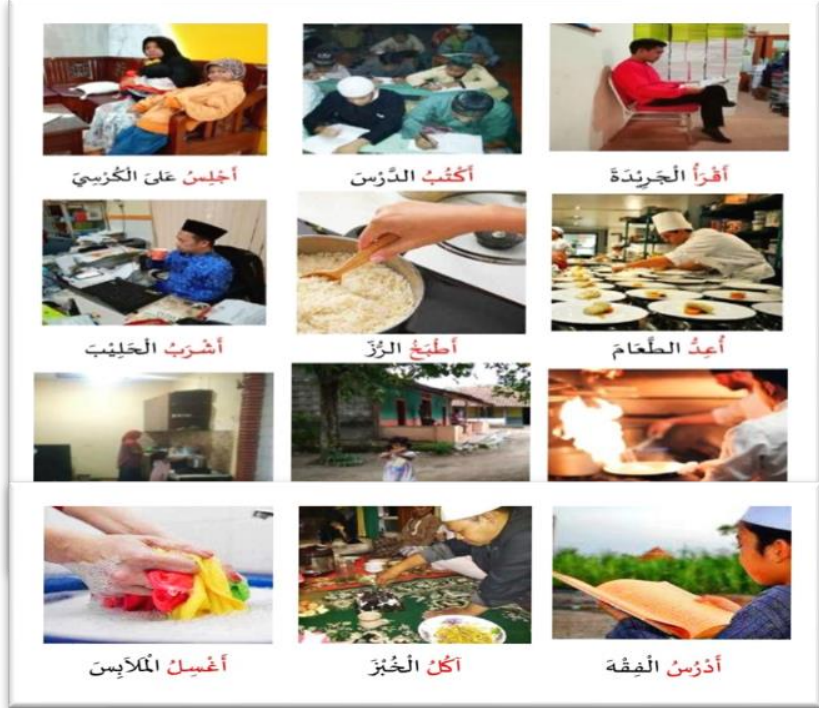

\section{Bias gender dalam peran kerja pada gambar ilustrasi}

Ditemukan bias gender dalam peran kerja yang terdapat dalam gambar ilustrasi dan pada materi, dimana perempuan dibebankan dengan pekerjaan merawat anak di rumah (sektor domestik) dan laki-laki bekerja di Kantor (sektor publik). Terlihat pada penjelasan ketika penulis menjelaskan pekerjaan rumah di sektor publik, maka dominasi perannya diisi oleh gender laki-laki. Fenomena seperti ini menyebabkan marginalisasi terhadap perempuan. Secara spesifik, pada Buku Bahasa Arab Karya Faruq Baharudin, Bias gender tersebut terdapat dalam bab enam yakni tema min yaumiyyatil usroh (Kegiatan sehari-hari). Ilustrasi dalam bab enam menggambarkan peran publik laki-laki yang bekerja di luar rumah seperti bekerja di kantor dan restoran.

Gambar ilustrasi yang mengonstruksikan bias gender dapat ditemukan pada gambar أَجْلِنُ عَلَى الْكُرْسِيّ yang menunjukkan seorang Ibu yang sedang duduk di ruang tamu dengan dua orang anaknya. Kemudian أَسْكُنُ فِى الْبَيْت (Aku tinggal di rumah) yang diilustrasikan oleh anak perempuan. Hal tersebut mengilustrasikan bahwa dalam kehidupan sehari-hari, perempuan diidentikkan dengan pekerjaan merawat anak dan tinggal di rumah, dengan kata lain perempuan ada pada sektor domestik. Sedangkan ilustrasi أَنْرَبُ الََْليْب (Aku meminum susu) diperankan oleh laki-laki 
dengan latar belakang kantor, yang menandakan tokoh laki-laki bekerja di kantor atau dalam sektor publik.

Pekerjaan rumahtangga yang bersifat domestik dibebankan kepada perempuan. Bahkan dalam hal bantu membantu, anak perempuan dari kecil sudah diajarkan untuk membantu urusan rumah tangga. Seperti pada gambar أُسَّاعِدُ أُبِّى terdapat ilustrasi seorang anak perempuan yang sedang membantu Ibunya memasak di dapur. Padahal pekerjaan membantu Ibu di dapur tidak harus diperankan oleh anak perempuan, tetapi bisa saja diperankan oleh anak laki-laki. Akan tetapi, jika pekerjaan tersebut keluar ke wilayah publik, biasanya posisinya

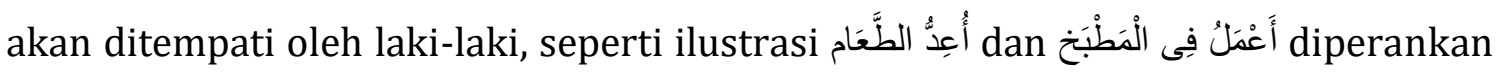
oleh chef dengan jenis kelamin laki-laki. Hal seperti ini juga dapat dikategorikan sebagai bias gender dalam peran kerja. (Faruq Baharudin, 2020: 119-120)

Dominasi laki-laki akan pekerjaan publik ini juga tidak lepas dari konstruksi sosial yang melekatkan laki-laki sebagai pribadi yang aktif serta pantas bekerja di luar rumah. Perempuan tetap dilekatkan dengan kewajiban menjadi ibu rumah tangga yang bertanggung jawab pada urusan keluarga di rumah seperti membersihkan rumah, memasak, dan merawat anak. Dominasi perempuan dalam kegiatan domestik ini tidak lepas dari anggapan masyarakat yang menganggap bahwa perempuan tidak produktif. Hal ini mengakibatkan peran kerja perempuan berkutat pada peran-peran domestik agar bisa merawat dan mengawasi anakanaknya.

Aktivitas domestik sudah sejak lama dilekatkan pada perempuan. Perempuan dianggap tidak dapat berkontribusi secara aktif di luar rumah (Darmin Tuwu, 2018: 74-75). Pernyataan tersebut didukung dengan hasil penelitian Zahratul Umniyyah ketika meneliti novel Kenanga karya Oka Rusmini. Dalam jurnalnya dikatakan bahwa marginalisasi terhadap perempuan sudah terjadi sejak berada di lingkungan keluarga dalam bentuk diskriminasi atas anggota keluarga. Marginalisasi tidak hanya terjadi di lingkungan rumah tangga, akan tetapi hal ini juga terjadi di tempat kerja (Zahratul Umniyyah, 2020). Wilayah domestik seringkali dilekatkan tanggungjawabnya pada perempuan (Fadhilah, N. 2020). Namun, ketika pekerjaan tersebut masuk ke area publik, biasanya posisinya akan digantikan oleh laki-laki, seperti contohnya memasak. Memasak ketika dilakukan di 
sektor publik, maka perannya diisi oleh laki-laki. Fenomena seperti ini menyebabkan marginalisasi terhadap perempuan Farmawati, C. (2018).

\section{Bias gender dalam nilai sifat pada gambar ilustrasi}

Gambar ilustrasi dalam bab enam tema min yauliyyatil usroh (Kegiatan seharihari) sebagaimana pada gambar 6 di atas, tidak ada satupun yang menggambarkan perempuan bekerja di luar rumah. Secara tidak langsung, gambar ilustrasi yang menampilkan laki-laki bekerja di luar dan perempuan ada di dalam rumah mensosialisasikan fenomena bias gender. Adanya bias gender dalam nilai sifat terbentuk dari cara pandang masyarakat yang menganggap kodrat perempuan adalah makhluk yang lemah sehingga lebih cocok jika berada di rumah dan menjadi ibu rumah tangga.

Dalam ilustrasi bab 6 di atas, jelas tergambar bahwa untuk hal-hal yang terlihat intelektual diilustrasikan oleh tokoh laki-laki seperti yang terdapat pada ilustrasi أَفْرَأ الْجرِيْدَة danana terdapat ilustrasi beberapa anak laki-laki sedang menulis pelajaran dan seorang laki-laki yang sedang membaca Koran. Akan tetapi, dari semua gambar ilustrasi yang ditampilkan, tidak ada satupun ilustrasi yang mensosialisasikan tokoh dengan jenis kelamin perempuan sedang melakukan pekerjaan di wilayah publik (Faruq Baharudin, 2020: 120).

Hubungan kerja dalam masyarakat patriarkhi berjalan secara tidak seimbang. Laki-laki menjadi individu yang lebih dihargai dalam suatu pekerjaan dibandingkan dengan pekerja perempuan. pekerjaan yang dianggap pantas untuk dilakukan perempuan adalah pekerjaan yang berhubungan dengan feminisme. Begitu juga sebaliknya, laki-laki diberikan pekerjaan yang berhubungan dengan sifat maskulin (Netty Dyah Kurniasari, 2015). Oleh karena itu, dalam masyarakat ada pekerjaan yang dianggap cocok dikerjakan oleh perempuan dan ada juga pekerjaan yang dianggap cocok untuk dilakukan oleh laki-laki. Hal ini diperkuat oleh teori dari Khusnul Khotimah yang menyebutkan bahwa pekerjaan yang diperuntukkan bagi laki-laki umumnya yang memerlukan otot lebih kuat, tingkat resiko dan bahayanya lebih tinggi karena bekerja di luar rumah, dan tingkat keterampilan yang tinggi. Adapun pekerjaan yang diperuntukkan untuk perempuan adalah pekerjaan dengan 
tingkat resiko lebih rendah, cenderung bersifat mengulang, dan tidak memerlukan banyak konsentrasi.

\section{Bias gender dalam status sosial pada gambar ilustrasi}

Bias gender dalam bab enam tema min yaumiyyatil usroh (Kegiatan seharihari) sebagaimana gambar 4 diatas, terdapat penggambaran Ibu memasak makanan di dapur yang terulang beberapa kali dan tokoh laki-laki yang digambarkan sedang makan roti, minum susu, dan membaca Koran (Faruq Baharudin, 2020:120). Hal tersebut membentuk citra baku (stereotip) perempuan yang identik dengan peran domestik, salah satunya memasak. Kemudian gambar ilustrasi yang menampilkan seorang anak perempuan yang membantu Ibu memasak di dapur dan tinggal di rumah kemudian ilustrasi anak laki-laki yang sedang belajar dan membuka buku. Selain itu, terdapat pula gambar أَسْكُنُ فِى الْبَيْتِ

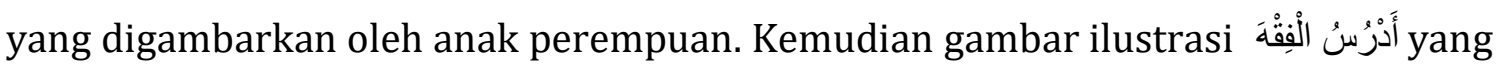
mengonstruksikan anak laki-laki sedang belajar fiqih. Kedua gambar tersebut mensosialisasikan bahwa laki-laki lebih identik dengan belajar dan mendapatkan pendidikan sedangkan perempuan tetap di rumah. Dari hal tersebut dapat diambil kesimpulan bahwa kesempatan dalam mendapatkan pendidikan dan mengembangkan skill yang dimiliki antara tokoh berjenis kelamin laki-laki dan perempuan dalam ilustrasi tersebut masih mengandung bias (Faruq Baharudin, $2020,120)$.

Dalam pernyataan tersebut, perempuan hanya diberi peran membantu, tidak melakukan pekerjaan sendiri secara mandiri. Berbeda dengan laki-laki yang telah diberi peran mandiri yang dikonstruksikan dengan kegaiatan belajar yang dilakukan secara mandiri. Padahal, perempuan juga bisa melakukan sesuatu yang sesuai dengan kehendaknya sendiri. Berdasarkan konstruksi sosial budaya, istilah gender merujuk pada perbedaan karakter laki-laki dan perempuan yang merujuk pada sifat, status, posisi, dan perannya dalam masyarakat. Nilai dan norma tradisional menempatkan kedudukan perempuan lebih rendah dari laki-laki. Keterbelakangan perempuan menyebabkan ruang gerak perempuan lebih sempit dari laki-laki dan menyebabkan terjadinya subordinasi terhadap perempuan. 
Pernyataan tersebut sesuai dengan ungakapan Heppy Atma Pratiwi dan Endang Wiyanti yang menyebutkan bahwa dalam keluarga di Indonesia pada umumnya telah disosialisasikan peran anak laki-laki dan perempuan secara berbeda. Anak laki-laki diminta membantu orangtua dalam hal tertentu, bahkan seringkali diberi kebebasan untuk bermain dan tidak dibebani tanggungjawab tertentu. Sedangkan anak perempuan diperlakukan sebaliknya, yaitu diberi tanggungjawab untuk membantu pekerjaan yang menyangkut urusan rumah seperti membersihkan rumah, memasak, dan mencuci (Heppy Atma Pratiwi dan Endang Wiyanti, 2017). Begitu juga dalam hal pendidikan, ketika kondisi ekonomi dalam suatu keluarga tidak memungkinkan untuk mencukupi biaya pendidikan semua anak, maka yang biasanya dikorbankan untuk tidak melanjutkan ke jenjang sekolah yang lebih tinggi adalah anak perempuan, sedangkan anak laki-laki tetap melanjutkan sekolah (Rustan Efendy, 2014). Laki-laki dipandang lebih penting dalam hal pendidikan sebab kelak kaum laki-laki yang akan mencari nafkah untuk keluarga, sedangkan perempuan tetap akan menjadi ibu rumah tangga.

\section{Bias gender dalam kegemaran pada gambar ilustrasi}

Gambar ilustrasi dalam bab enam sebagaimana dalam gambar di atas, menggambarkan bahwa tokoh laki-laki bentuk kegemarannya dikonstruksikan dengan membaca Koran, meminum susu, dan belajar. Sedangkan tokoh perempuan kegemarannya dikontruksikan dengan memasak, mencuci baju, dan bermain. Padahal, kegiatan-kegiatan tersebut juga bisa dilakukan oleh laki-laki maupun perempuan. Kemudian bias gender dalam kegemaran yang terdapat dalam gambar ilustrasi selain dalam bentuk aktivitas yang dilakukan, juga terkonstruksi melalui benda-benda yang dimiliki dan digunakan. Hal ini terdapat pada pakaian yang digunakan oleh tokoh laki-laki dan perempuan dalam gambar ilustrasi tersebut. Laki-laki dan perempuan dibedakan melalui karakteristik cara berpakaian. Ilustrasi dalam bab enam menggambarkan cara berpakaian laki-laki lebih sering menggunakan kemeja dan celana panjang, sedangkan perempuan digambarkan dengan menggunakan rok atau baju terusan serta pemakaian kerudung pada penggambaran beberapa tokoh. Kesamaan dalam menggunakan celana panjang bisa saja terjadi dalam beberapa aktivitas yang berarti tidak terikat milik laki-laki 
atau perempuan. Namun, untuk rok, kerudung, dan baju terusan melekat pada kepemilikan perempuan (Nurliana dan Rahmat Hidayat, 2021).

\section{KESIMPULAN}

Hasil analisis yang peneliti lakukan pada buku teks pelajaran bahasa Arab kelas VII karya Faruq Baharudin tahun 2020 masih mengandung bias gender. Berikut kesimpulan yang dapat peneliti ambil dari dua rumusan masalah. Pertama, Materi dalam buku teks pelajaran bahasa Arab karya Faruq Baharudin masih mengandung bias gender baik dari segi peran kerja, nilai sifat, status sosial, maupun kegemaran. Bias gender ini terdapat dalam tiga tema dari enam tema yang ada dalam buku ini, yaitu bab satu tema ta'aruf (Perkenalan), bab tiga tema adawatul madrosiyyah (Peralatan sekolah), dan bab enam tema min yaumiyyatil usroh (Kegiatan sehari-hari keluarga).

Sementara untuk Bias gender dalam gambar ilustrasi buku teks pelajaran bahasa Arab karya Faruq Baharudin. Dari empat gambar ilustrasi yang terdapat dalam buku teks pelajaran bahasa Arab karya Faruq Baharudin, ada satu gambar ilustrasi yang mengandung bias gender, yaitu terdapat pada tema enam tentang min yaumiyyatil usroh (kegiatan sehari-hari keluarga), yang dianalisis dalam empat aspek yaitu peran kerja, nilai sifat, status sosial, dan bias gender dalam kegemaran. Meski begitu, buku ini juga dilengkapi dengan gambar ilustrasi yang responsif gender seperti ilustrasi profesi yang terdapat dalam tema satu tentang ta'aruf (Perkenalan), yaitu ilustrasi profesi digambarkan dengan tokoh laki-laki dan perempuan.

Dari hasil penelitian dan kesimpulan yang telah dikemukakan sebelumnya, penulis seyogyanya melakukan evaluasi pada buku teks pelajaran bahasa Arab. Dalam penyusunan buku ajar bahasa Arab diharapkan agar selalu memperhatikan nilai-nilai yang terkandung di dalamnya, salah satunya dengan memperhatikan nilai kesetaraan gender dalam materi dan gambar ilustrasi yang ditampilkan dalam buku. Kemudian bagi guru diharapkan selektif dalam memilih buku ajar yang responsif gender. Dalam menyikapi buku pelajaran yang masih bias gender, 
hendaknya guru menyampaikan materi diimbangi dengan contoh dan pembahasan yang memuat nilai kesetaraan gender sehingga sosialisasi bias gender di sekolah dapat diminimalisir.

Melalui hasil analisis materi dan gambar ilustrasi bias gender dalam penelitian ini, direkomendasikan kepada pemangku kebijakan pendidikan, pengembang kurikulum dan guru-guru Bahasa Arab khususnya untuk menelaah dan mengoreksi kembali akan representasi gender dalam buku teks yang digunakan di lingkungan pendidikan sehingga dapat memastikan representasi gender yang adil dalam materi pendidikan di Indonesia.

\section{DAFTAR PUSTAKA}

Afandi, A. (2019). Bentuk-Bentuk Perilaku Bias Gender . LENTERA: Journal of Gender and Children Studies , 1-17.

Ani. (2017). Perempuan dan Karir (Telaah Teori Trait and Factor dalam Pengembangan Karir dan Pengambilan Keputusan). MUWAZAH , 151-161.

Astuti, S. I. (2007). Panduan Untuk Melaksanakan Penelitian dalam Kajian Media dan Budaya. Yogyakarta: PT Bentang Pustaka.

Baghdadi, M., \& Rezaei, A. (2015). Gender representation in english and Arabic foreign language textbooks in Iran: A comparative approach. Journal of International Women's Studies, 16(3), 16-32.

Cépeda, P., Kotek, H., Pabst, K., \& Syrett, K. (2021). Gender bias in linguistics textbooks: Has anything changed since Macaulay \& Brice 1997?. Language.

Dawar, T. I. N. N. Y., \& Anand, S. A. R. I. T. A. (2017). Gender bias in textbooks across the world. International Journal of Applied Home Science, 4, 224-235.

Dewi Ulfah, I. d. (2019). Bias Gender dalam Buku Teks Pelajaran Bahasa Indonesia Sekolah Menengah Atas. RETORIKA: Jurnal Bahasa, Sastra, dan Pengajarannya , 188-197.

Efendy, R. (2014). Kesetaraan Gender dalam Pendidikan . Jurnal Al-Maiyyah , 142165. 
Elmiana, D. S. (2019). Pedagogical representation of visual images in EFL textbooks: a multimodal perspective. Pedagogy, Culture \& Society, 27(4), 613-628.

Erlina. (2013). Perspektif Gender dalam Buku Teks Bahasa Arab "Al-Arabiyah Baina Yadaika". Jurnal Al-Bayan , 19-31.

Faruq Baharudin, Bahasa Arab Madrasah Tsanawiyah kelas VII, cetakan pertama: 2020 (Jakarta: Kementerian Agama RI, 2020), hlm. 1-144

Farmawati, C. (2018). Peningkatan Peran Masyarakat dalam Pencegahan KDRT Melalui Penyuluhan Anti Kekerasan Berbasis Gender. MUWAZAH: Jurnal Kajian Gender, 10(2), 138-161.

Fadhilah, N. (2020). Kecenderungan Perilaku Seksual Beresiko Dikalangan Mahasiswa: Kajian Atas Sexual Attitude Dan Gender Attitude. Marwah: Jurnal Perempuan, Agama Dan Jender, 19(2), 171-189.

Ferree, M. M., \& Hall, E. J. (1990). Visual images of American society: Gender and race in introductory sociology textbooks. Gender \& Society, 4(4), 500-533

Forcey, L. R. (2016).Feminist Perspectives on Mothering and Peace 1. In Mothering (pp. 355-375). Routledge.

Foroutan, Y. (2012). Gender representation in school textbooks in Iran: The place of languages. Current Sociology, 60(6), 771-787.

Handayani, R. (2020). Multi Peran Wanita Karir pada Masa Pandemi Covid-19. Jurnal Kajian Gender dan Anak , 1-10

Hedge, T. (2001). Teaching and learning in the language classroom (Vol. 106). Oxford, UK: Oxford university press.

Hidayat, R. (2011). Bias Gender dalam Prestasi Akademik Siswa: Studi Tentang Perbandingan Prestasi Akademik Siswa Laki-laki dan Perempuan di SMA 12 Bekasi . Jurnal Pendidikan dan Kebudayaan , 472-479.

Izzuddin, Dalimunthe, R. P., \& Susilo, S. (2021). The Portrayal of Women in Arabic Textbooks for Non-Arabic Speakers. SAGE Open, 11(2), 21582440211014184. Janu Arbain, N. A. (2015). Pemikiran Gender Menurut Para Ahli: Telaah Atas Pemikiran Amina Wadud Muhsin, Asghar Ali Engineer, dan Mansour Fakih. SAWWA , 75-94. 
Julianti, L., \& Ikhsanudin, I. (2019). A Content Analysis of Gender Bias in When English Rings A Bell Textbooks. International Journal of Learning and Instruction (IJLI), 1(1), 23-30.

Lasaiba, D. (2016). Gender Relation dalam Buku Ajar Bahasa Inggris Sekolah Dasar. Jurnal al-iltizam , 1-16.

Listiyani, B. N. (2017). Bias Gender dalam Buku Tematik Siswa Kurikulum 2013 (Studi Semiotika Ketidaksetaraan Gender dalam Pendidikan). PARADIGMA , 18.

Luthfiyah Zahro, A. J. (2020). Profil Kemampuan Berfikir Logis Siswa SMP Kelas VII Berbasis dengan Gender. Jurnal Pelita Pendidikan , 134-137.

Mengel, F., Sauermann, J., \& Zölitz, U. (2019). Gender bias in teaching evaluations. Journal of the European Economic Association, 17(2), 535-566.

Mim, S. A. (2019). Women Missing in STEM Careers: A Critical Review through the Gender Lens. J. Res. Sci. Math. Technol. Educ, 2, 59-70.

Nofianti, L. (2016). Perempuan di Sektor Publik. marwah , 51-61.

Nur Alifta Kinanti, M. I. (2021). Stereotip Pekerjaan Berbasis Gender dalam Konteks Indonesia. Jurnal Manajemen dan Usahawan Indonesia , 1-16.

Pratama, M. N. (2019). Tantangan dan Kesempatan Wanita dalam Lingkungan Kerja. DERIVATIF: Jurnal Manajemen , 8-15.

Remiswal. (2013). Menggugah Partisipasi Gender di Lingkungan Komunitas Lokal. Yogyakarta: Graha Ilmu.

Rohmawati, T. T. (2018). Segresi Gender dalam Manajemen Peserta Didik di Lembaga Pendidikan Islam. Martabat: Jurnal Perempuan dan Anak , 287-314.

Selvi, A. F., \& Kocaman, C. (2021). (Mis-/Under-) Representations of gender and sexuality in locally-produced ELT materials. Journal of Language, Identity \& Education, 20(2), 118-133.

Shodiq, M. J. (2014). Bias gender dalam buku bahasa Arab siswa MA kelas X dengan pendekatan saintifik 2013. Jurnal Pendidikan Islam, 3(2), 307-326.

Shodiq, M. J. (2016). Perspektif Kesetaraan Gender dalam Buku Bahasa Arab Siswa MTs Pendekatan Saintifik 2013. FENOMENA , 1-18.

Subhan, Z. (2015). Al-Qur'an dan Perempuan: Menuju Kesetaraan Gender dalam Penafsiran. Jakarta: Kencana. 
Sulaimani, A. (2017). Gender Representation in EFL Textbooks in Saudi Arabia: A Fair Deal?. English Language Teaching, 10(6), 44-52.

Sumar, W. T. (2015). Implementasi Kesetaraan Gender dalam Bidang Pendidikan. MUSAWA , 158-182.

Suwardi, S., Anitah, S., Akhyar, M., \& Asrowi, A. (2017). Gender bias in Islamic textbooks for Muslim children in Indonesia. ATTARBIYAH: Journal of Islamic Culture and Education, 2(2), 214-235.

Tuwu, D. (2018). Peran Pekerja Perempuan dalam Memenuhi Ekonomi Keluarga: dari Peran Domestik Menuju Sektor Publik. Al Izzah: Jurnal Hasil-Hasil Penelitian , 63-76.

Umar, N. (2010). Argumen Kesetaraan Gender. Jakarta: Dian Rakyat.

Umniyyah, Z. (2020). Marginalisasi Perempuan: Cara Pandang Masyarakat Penganut Sistem Patriarki dalam Novel Kenanga Karya Oka Rusmini. Jurnal Unej , 120-129.

Wiasti, N. M. (2017). Mencermati Permasalahan Gender dan Pengarusutamaan Gender (PUG). Sunari Penjor: Journal of Anthropology , 29-42.

Wiyanti, H. A. (2017). Representasi Kesetaraan Gender pada Iklan (Tinjauan Semiotika Citra Laki-laki dalam Keluarga pada Iklan Televisi). Jurnal Desain , 212-230.

Yonata, F., \& Mujiyanto, Y. (2017). The representation of gender in English textbooks in Indonesia. Language Circle: Journal of Language and Literature, 12(1), 91-102

Zahro, A. (2020). Gender Responsivity in a Junior High School Indonesian Language Textbook. Talent Development \& Excellence, 12(1).

Zulifan, M. (2018). Bahasa Arab Untuk Semua Metode Praktis Memahami BahasaArab dan Al-Qur'an. Jakarta: PT Gramedia. 